\title{
ENDOCARDIAL FIBROELASTOSIS WITH GENERALIZED LYMPHADENOPATHY, EDEMA, AND RASH
}

\author{
BY \\ N. M. GIBBS, J. C. HAWORTH, AND JOHN RENDLE-SHORT \\ From the Department of Child Health, The University of Sheffield, and The Children's Hospital, Sheffield
}

Received December 22, 1955

Endocardial fibroelastosis of the heart has attracted much attention in recent years and published case reports have been fully reviewed by Blumberg and Lyon (1952), Gowing (1953), and Dennis et al. (1953). A further review would seem unjustified, but we wish to report two cases of endocardial fibroelastosis associated with unusual clinical and pathological features.

\section{CASE REPORTS}

Case 1. This boy was perfectly well until the age of eight and a half months when he developed a running nose with intermittent pyrexia and cough and his cervical lymph nodes were noticed to be enlarged. At the age of ten months his mother observed that he had a swelling in the left groin and that his feet and face were swollen. His urine was found to contain albumin. He was admitted to the Montagu Hospital, Mexborough, under the care of Dr. C. C. Harvey and at eleven months was transferred to the Sheffield Children's Hospital. On admission he was a pale, ill-looking child weighing $10.6 \mathrm{~kg}$. with pitting œdema over his legs and back. He had a generalized enlargement of his lymph nodes, one in the left groin being especially prominent. His liver and spleen were both easily palpable but no other abnormal physical signs were detected. His heart at that time was thought to be normal. His blood pressure was 95/55.

Investigations. Urine: albumin $300 \mathrm{mg}$. per $100 \mathrm{ml}$., with an occasional granular cast but no red blood corpuscles. Hæmoglobin: $10.8 \mathrm{~g}$. per $100 \mathrm{ml}$. W.B.C.: 3500 per c.mm. with a normal differential count. Bone marrow: hypercellular marrow with an increase in megakaryocytes including some abnormal forms: an abnormal marrow showing non-specific changes.

Blood cholesterol: $238 \mathrm{mg}$. per $100 \mathrm{ml}$. Blood urea: $28 \mathrm{mg}$. per $100 \mathrm{ml}$. Serum albumin: $2.4 \mathrm{~g}$. per $100 \mathrm{ml}$. Serum globulin: $1.9 \mathrm{~g}$. per $100 \mathrm{ml}$. Electrophoresis of the serum showed a decreased albumin and an increase of alpha 2 globulin; beta and gamma globulin were present in normal amounts. A four-day fat balance was normal.

A radiograph of the chest showed no abnormality. The Wassermann reaction was negative on mother and child. A posterior occipital node biopsy was performed. The findings will be discussed in the report of the pathological specimens.

Progress and Treatment. The child's condition grew gradually worse during the next six weeks. He developed small pleural effusions which were aspirated, the fluid containing $1000 \mathrm{mg}$. of protein per $100 \mathrm{ml}$., with a specific gravity of 1015 . His urine never contained more than 12 R.B.C.'s per high-power field, but the albumin content rose to $900 \mathrm{mg}$. per $100 \mathrm{ml}$. At this stage he was a grossly odematous child who preferred to sit upright in bed. As it was thought that he probably had the nephrotic syndrome, cortisone was given by mouth for seven days, but no diuresis occurred when the drug was withdrawn. Indeed, his œdema and dyspnœa grew worse and his pleural effusions were again aspirated, a total of $205 \mathrm{ml}$. of fluid being removed. Mersalyl $\frac{1}{2} \mathrm{ml}$. was 
given intramuscularly and this produced a diuresis, although the œdema did not entirely disappear. Because of the satisfactory response to the drug, mersalyl $1 \mathrm{ml}$. was continued every other day, but the child became increasingly dyspnœic. Ten days before his death at the age of 13 months an apical systolic murmur was heard for the first time.

Necropsy Findings. The body was that of a male child weighing $8.8 \mathrm{~kg}$. with generalized pitting œdema of the subcutaneous tissues. The œdema was most marked in the tissues of the face. There were large pleural effusions of $120 \mathrm{ml}$. on each side. The pericardium and pericardial cavity were normal. No ascites was present.

Cardiovascular System. The heart weighed 65 g. (normal 45 g.) and showed hypertrophy of the muscle of all chambers (left ventricle $9.0 \mathrm{~mm}$., right ventricle $4.0 \mathrm{~mm}$.). The endocardium was opaque with a pearly white colour. It was thickened throughout, that in the atria measuring $1.0 \mathrm{~mm}$. and the ventricles $2.0 \mathrm{~mm}$. The atrial walls showed no tendency to collapse after evacuation of blood clot, owing to the rigidity of the endocardium: thus the orifices of the venæ cavæ, auricular appendices, coronary sinus, and pulmonary veins remained widely patent. The mitral valve cusps were thickened and the valve orifice was converted into a rigid contracted opening. The remaining valves showed no abnormality. The coronary arteries were normal in appearance and distribution.

Other Organs. There was generalized enlargement of the lymph nodes, the mediastinal nodes showing the most conspicuous changes. On section the surfaces had a cystic appearance and exuded clear watery fluid. Both lungs were partially collapsed, congested, and œdematous. The liver weighed 317 g. (normal 304 g.). It was pale in colour. There was some enlargement of the spleen which weighed 38 g. (normal 26 g.). The kidneys (right 45 g., left 51 g., normal 35 g.) were enlarged, pale, and œdematous. There was no evidence of subcapsular or parenchymal scarring: the renal pattern was normal.

The histological findings will be discussed with those of Case 2.

Case 2. A previously healthy boy of four months was admitted to hospital with a left-sided otitis media and mastoiditis. A few râles were heard in his chest. He responded quickly to treatment with penicillin and was discharged home after four days. Ten days later his cough became worse, he went off his feeds and was noted to be generally unwell. After a further two weeks he was readmitted to hospital looking ill and weighing $9 \cdot 1 \mathrm{~kg}$. He was afebrile but was in some respiratory distress and bronchial breathing was audible at the left lung base. There was a large, tender, submandibular lymph node on the left side, and an urticarial rash on the trunk. An X-ray of the chest showed collapse of the left lower lobe. He was treated with intramuscular penicillin, 250,000 units six-hourly. The signs in the chest cleared in ten days and the submandibular node subsided. His urine contained albumin $1600 \mathrm{mg}$. per $100 \mathrm{ml}$., with an occasional pus cell and red blood cell.

He was seen as an outpatient about three weeks later when bronchial breathing was again heard at the left lung base and there were signs of generalized bronchitis. A further chest X-ray showed that the collapse of the left lower lobe persisted.

This child's third admission was at the age of seven months when there was increasing respiratory difficulty. Examination revealed a pale, ill baby who had some puffiness of the face but no detectable œdema elsewhere. There was a fine petechial rash on the neck, and brownish markings on the trunk looked like fading petechiæ. The signs in the chest were unchanged and he had a left suppurative otitis media. No abnormality was detected in the cardiovascular system. The urine contained $600 \mathrm{mg}$. per $100 \mathrm{ml}$. of albumin, but no increase in cells and no casts. A tentative diagnosis of nephrotic syndrome was made. He was given penicillin without much improvement and later aureomycin was substituted for the penicillin.

Investigations. Hæmoglobin: 10.4 g. per $100 \mathrm{ml}$. W.B.C.: 8000 per c.mm. with normal differential count. Platelets: 401,000 per c.mm. Serum proteins: albumin $2.5 \mathrm{~g}$. per $100 \mathrm{ml}$., globulin $1.7 \mathrm{~g}$. per $100 \mathrm{ml}$. Electrophoresis: increased alpha 2 globulin and decreased beta globulin. Serum cholesterol: 224 and $179 \mathrm{mg}$. per $100 \mathrm{ml}$. Blood urea: $25 \mathrm{mg}$. per $100 \mathrm{ml}$.

The patient's general condition remained unchanged and the cough and aural discharge per- 
sisted. Two and a half weeks after admission he developed diarrhœa and vomiting and was reluctant to feed. The next day he was very ill and dehydrated. Intravenous fluids were given. Two days later, because of persisting diarrhœa, he was transferred to an isolation hospital.

He was readmitted from the isolation hospital after a further six weeks. His general condition wás poor, and he had slight generalized œdema. He was cyanosed and in considerable respiratory distress. There were signs of a left-sided pleural effusion. He had a temperature of $99^{\circ} \mathrm{F}$. Lymph nodes in the neck, axillæ, and groins were moderately enlarged and the spleen was easily palpable. There was a blotchy rash on the trunk which had a purpuric element (Fig. 1). The

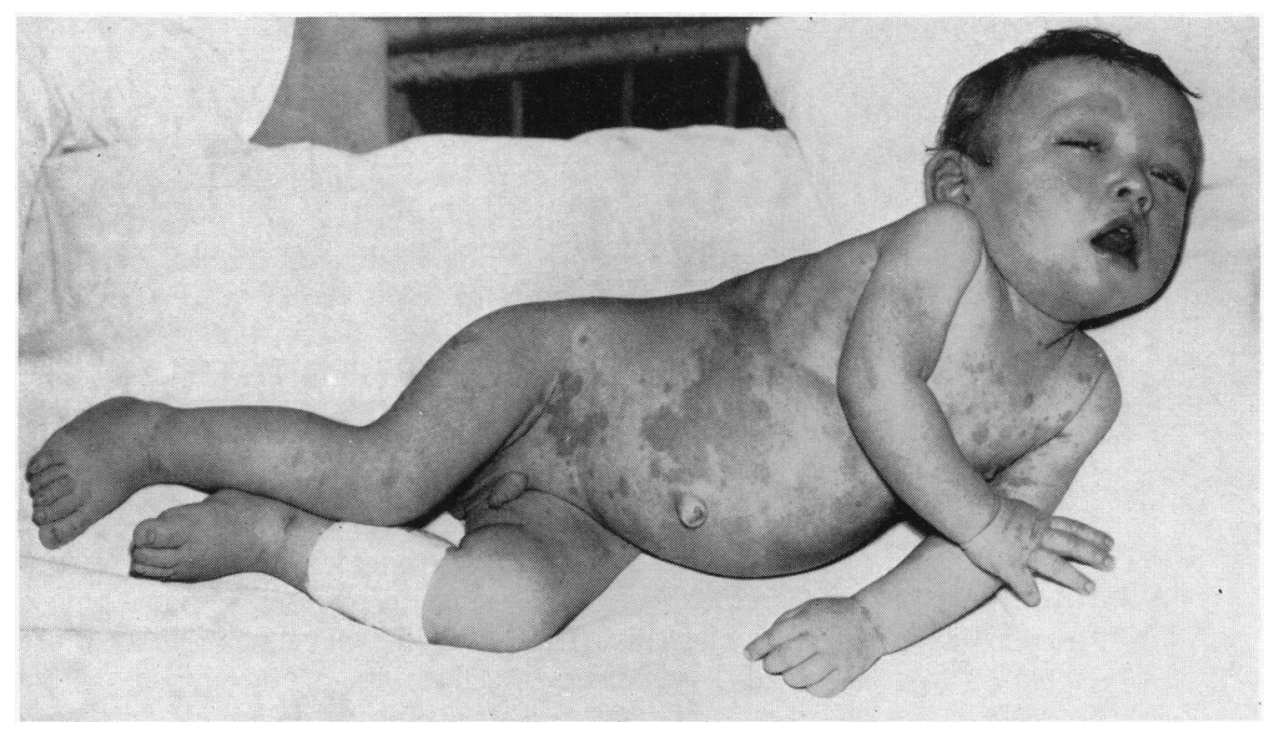

Fig. 1.-Appearance of Case 2 during the fourth hospital admission.

heart was thought to be normal and there was no hypertension. Chest aspiration yielded $105 \mathrm{ml}$. of straw-coloured fluid which clotted readily and contained 850 leucocytes per c.mm., mainly lymphocytes. This fluid was sterile.

Other Investigations. Bone marrow biopsy, no gross abnormality. Kahn, and Wassermann reactions negative. Toxoplasma tests, negative. X-ray of chest: left-sided pleural effusion, collapse of the left lower lobe, partial collapse of the left upper lobe with herniation of the right lung across to the left; the heart shadow was partly obscured by fluid but was not thought to be enlarged.

Pleural aspiration was repeated on three occasions because of increasing respiratory difficulty, 140,60 , and $200 \mathrm{ml}$. of fluid being removed. Each time there was temporary improvement but the boy's general condition remained unchanged. The rash increased and involved the whole of the body. At this time adrenocorticotrophic hormone was given empirically, but seven days later the child's temperature rose and he died suddenly from respiratory failure. At the time of his death he was ten months old.

Necropsy Findings. The body was that of a well-nourished male child showing odema of the subcutaneous tissues. There was a large left-sided pleural effusion with some thickening of the parietal pericardium, but no adhesions were present. There was no ascites.

Cardiovascular System. The heart weighed 62 g. (normal 39 g.) and showed hypertrophy and dilatation of all chambers. The wall of the left ventricle measured $11 \mathrm{~mm}$., and that of the right ventricle $9 \mathrm{~mm}$. There was endocardial thickening which was similar in distribution and 
degree to that in Case 1. The endocardium of the atria was $1.0 \mathrm{~mm}$. thick and that of the ventricles $2.0 \mathrm{~mm}$. In addition the tricuspid valve cusps were thicker than normal and the mitral valve was reduced to a rigid contracted opening. The pulmonary and aortic valves appeared normal. The coronary arteries were also normal.

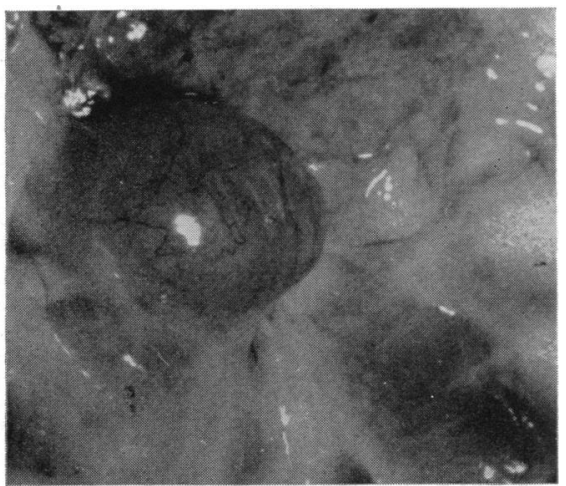

FIG. 2.-Internal mammary lymph cysts (Case 2).

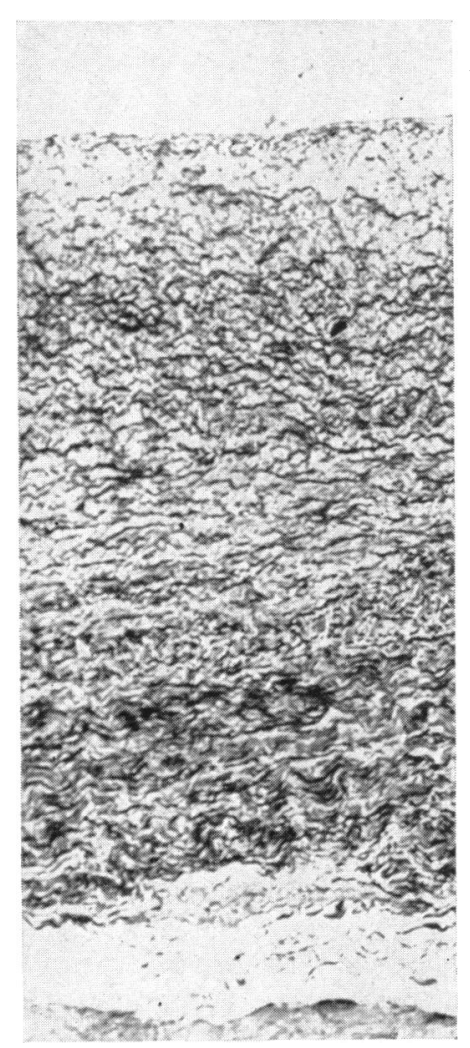

Fig. 3.-Endocardium of left auricle, $\times 75$ (Case 1). Weigert's resorsin fuchsin and Van Gieson.

Other Systems. The lymph nodes were distended with clear watery fluid. In particular the internal mammary lymph nodes were converted into thin-walled cysts (Fig. 2) and similar but less pronounced changes were present in the other lymph nodes. The lungs were collapsed, œdematous, and congested. The liver (448 g., normal 274 g.) and the spleen (30 g., normal 22 g.) were enlarged and firm. The kidneys (right $81 \mathrm{~g}$., left 79 g., normal 32 g.) were large and pale and showed no subcapsular or parenchymal scarring.

Histology. The histological appearances of the heart, lungs, lymph nodes, and kidneys were similar in each case. In the heart the endocardium of the atria and ventricles consisted of thick fibroelastic tissue, which showed some variation in structure: that of the atria was composed of collagen with regularly spaced nuclei and contained large numbers of delicately undulating elastic fibres (Fig. 3), whereas the endocardium of the ventricles consisted of almost acellular hyaline collagen and fragmented elastic fibres. The mitral valves in both cases and the tricuspid valve in Case 2 showed the typical changes that have been described in fibroelastosis (Craig, 1949). The ventricular muscle fibres showed hypertrophy. All lobes of the lungs of both cases showed œdema with alveolar collapse and congestion. Numerous hæmosiderin-containing macrophages were present within the alveoli.

Lymph nodes (including biopsy of posterior occipital lymph nodes in Case 1). Lymph nodes examined from each of the main groups showed great dilatation of the lymphatic sinuses which were filled with acellular lymph (Fig. 4 and 5). The lymph follicles contained plasma cells and mononuclear macrophages, in addition to lymphocytes. The lymph node capsules were occasionally thickened. Those of the internal mammary lymph nodes of Case 2 revealed the most conspicuous changes and were surrounded by cellular connective tissue. There was general dilatation of the lymphatics associated with interstitial œdema. The tissues adjacent to the lymphatic channels contained a few plasma cells and lymphocytes.

In both cases conspicuous interstitial œdema was seen in the kidneys with occasional foci of plasma cells and lymphocytes. The glomerular tufts and tubules were normal. In each case the lymphatics in the portal areas of the liver were distended with lymph (Fig. 6) and some intracellular fat droplets were demonstrated at the periphery of the liver lobules. The typical appearances of chronic venous congestion were not present.

The following additional histological lesions were found in 


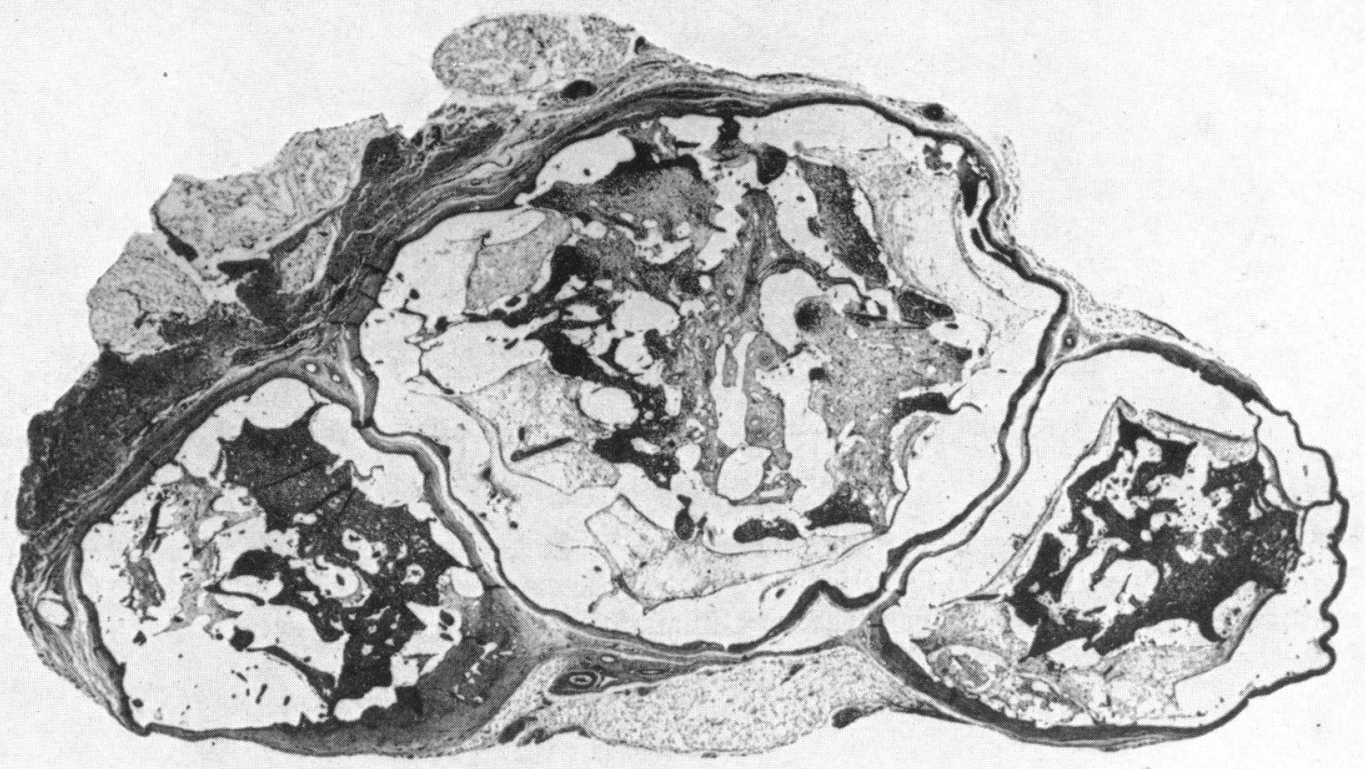

FIG. 4.-Biopsy of posterior occipital lymph node. Hæmatoxylin and eosin. $\times 8$. Case 1 .

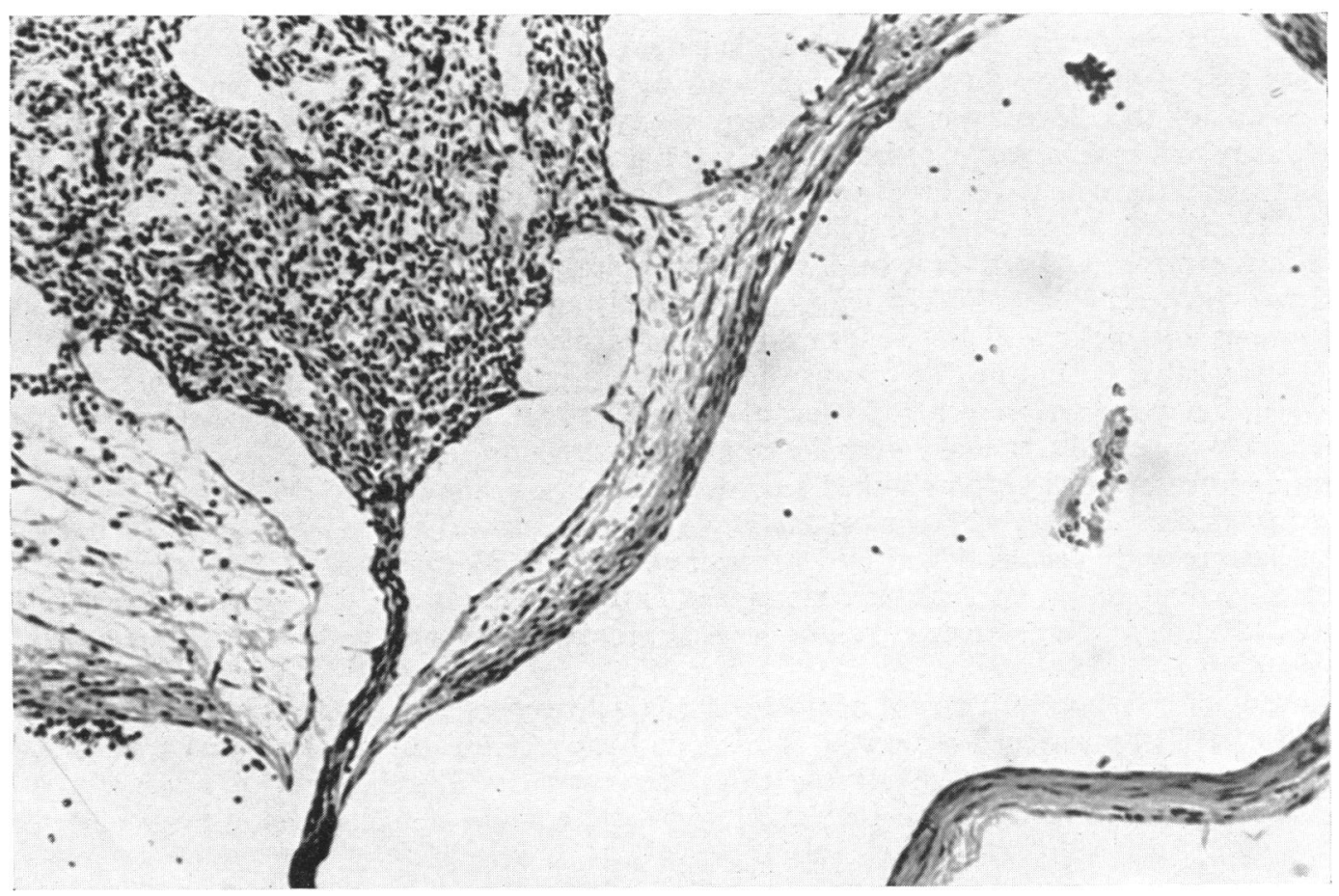

Fig. 5.-Lymph sinuses from node shown in Fig. 4. Hæmatoxylin and eosin. $\times 100$. 


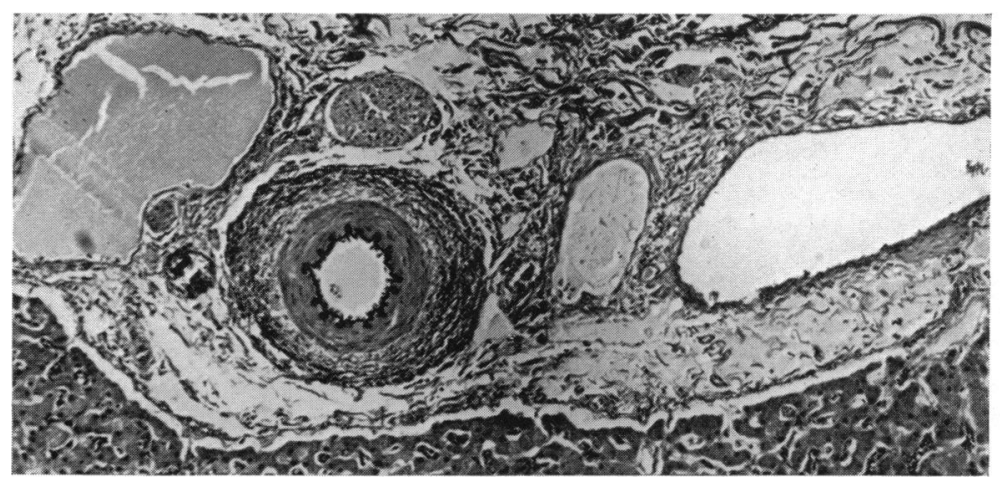

FIG. 6.-Portal lymphatics in liver. Verhœff hæmatoxylin and Van Geison. $\times 55$. Case 2 .

Case 2: the pericardium was composed of hyaline collagen, which contained no elastic fibres and was relatively avascular. The dermis of the skin showed changes similar to those seen in the interstitial tissues elsewhere, namely vascular dilatation and distended lymphatics. Lymphocytes and plasma cells were present. The epidermis was normal.

\section{Discussion}

The clinical features of the two cases were remarkably similar. They were boys of about the same age, being 13 and 10 months respectively when they died. They were both apparently quite healthy for the first few months of life and then presented with respiratory disease, œdema, and generalized lymphadenopathy. The urine of both children contained a large amount of albumin but very few red blood cells or casts were seen. Serum proteins were low in each case, with a reduction of the albumin fraction, and both children were at one time thought to be suffering from the nephrotic syndrome. The electrophoretic pattern, however, although similar in the two cases, was not typical of the nephrotic syndrome and the blood cholesterol was not appreciably raised. The course of the disease was slowly progressive, with increasing œdema and pleural effusions which required aspiration. Cortisone in Case 1 and adrenocorticotrophic hormone in Case 2 did not affect the course of the disease, and in fact these drugs may have precipitated the fatal issue. In neither case was cardiac failure seriously considered, although in Case 1 mersalyl caused some improvement and ten days before death an apical systolic murmur was heard. In neither child was the heart enlarged clinically or radiologically and retrospective examination of the chest radiographs does not reveal any abnormality of the cardiac silhouettes.

A remarkable feature in Case 2 was the rash. During the second hospital admission it was urticarial, but petechiæ were noted later; the platelet count, however, was normal. Large dark red blotches appeared terminally over the trunk and extremities.

In a survey of previously published records we have not been able to find reports of cases of endocardial fibroelastosis with clinical findings such as these. The clinical features of the condition have recently been reviewed by Dennis et al. (1953). Neither œdema, generalized lymphadenopathy, albuminuria, nor rash were mentioned in their review of the signs and symptoms of the disease. Radiographic enlargement of the heart was found in 85 per cent of cases in which radiology was performed.

Gowing (1953) described a case of fibroelastosis with generalized lymphadenopathy and Prior and Wyatt (1950) mentioned cases with mesenteric lymphadenopathy associated with ascites, but no additional details were given. In our cases the generalized lymphadenopathy was caused by extreme dilatation of the lymph node sinuses with lymph. The resulting lymph cysts were most 
conspicuous in the internal mammary nodes in Case 2 , where the lymph node capsules were thickened and surrounded by cellular connective tissue.

There are two possible reasons for the production of these lymph cysts: (1) increase in the volume of lymph flow or (2) lymphatic obstruction. An increase in the volume of lymph flow occurs when there is œdema of the interstitial tissues, but no previous account of generalized lymphadenopathy with the formation of lymph cysts has been found. Increased lymph flow might be expected to occur in congestive cardiac failure, and enlargement of the hilar lymph nodes has been recorded in this condition by Bouvrain and Bescol-Liversac (1950). Pathological evidence of systemic venous congestion in our cases was, however, lacking and in any case there is no reason why increased lymph flow per se should result in cyst formation. It would seem, therefore, that the second possibility, namely lymphatic obstruction, was the factor responsible for the formation of the lymph cysts. It was not possible to determine histologically whether the obstruction was in the lymph channels or in the nodes themselves.

In both our cases albuminuria was gross and continuous. Albuminuria of moderate degree is common in congestive cardiac failure and is attributed to changes in the permeability of the glomerular capillary loops produced by engorgement of the renal venous radicles, but as has been stated, no macroscopic or microscopic appearances of chronic venous congestion were found. In addition, no nephron lesions were identified, the enlargement and pallor of the kidneys being produced by interstitial odema. Dilated lymphatic channels were prominent and it is possible that the albuminuria was related to the deficient disposal of the interstitial fluid in the kidneys.

The fibroelastic process in our cases was unusually widespread and extensive. All chambers of the two hearts were involved, including the right atria, though the right side of the heart in this condition is generally much less often affected than the left. In 149 cases reviewed by Dennis et al. (1953) the process was limited to the left side in 82 per cent and only two reports of involvement of the right atrium has been found by us (Hill and Reilly, 1951; Collier and Rosahn, 1951). Both our cases showed thickening of the mitral valve and in Case 2 the tricuspid valve was also affected. Tricuspid stenosis was present in only 10 of 149 cases reviewed by Dennis et al.

Both our cases presumably died from cardiac failure, although the fact that chronic venous congestion was not found in the organs at necropsy would suggest that the failure was acute, and possibly only the terminal event in a generalized morbid process in which the heart, among other tissues, was involved. Certainly Case 2, right up to the end of his life, seemed to be suffering from an acute disease as evidenced by an intermittent temperature and a rash, which frequently changed in appearance.

The cause of cardiac failure in fibroelastosis remains uncertain. Gross (1941) and Weinberg and Himelfarb (1943) suggested that failure is the result of ischæmia of the subendocardial muscle produced by vascular stasis, this in turn resulting from obstruction of the Thebesian veins by the thickened endocardium. However, the endocardium in our cases was so much thickened and so rigid that it could easily be imagined that it interfered mechanically with the action of the heart and this, together with the valve lesions, precipitated failure. This supports one of the hypotheses of Prior and Wyatt (1950) and, indeed, it seems probable that the cardiac failure in endocardial fibroelastosis is similar in mechanism to that in constrictive pericarditis, for in each disease the action of the heart is impeded by a dense investment with connective tissue. It is interesting to speculate whether the unusual thickening of the endocardium in our cases prevented the chambers dilating and thus accounted for no cardiac enlargement being detected clinically.

The ætiology of endocardial fibroelastosis remains unknown. Kempton and Glynn (1955) have recently discussed the various suggestions made. Our two cases were characterized by an unusually diffuse involvement of the heart together with evidence of lymphatic obstruction and in addition, a generalized skin rash in Case 2. It seems reasonable to postulate that the endocardial fibroelastosis, lymphatic obstruction, albuminuria, and skin rash were all manifestations of a generalized disease, the origin of which remains obscure. 


\section{SUMMARY}

Two cases of endocardial fibroelastosis are presented. The clinical features of the cases showed a close similarity. After being healthy for the first few months of life, both boys developed respiratory infections, gross odema, generalized lymphadenopathy, albuminuria, and low serum albumin. In addition, one child had a rash.

The pathological findings in the two cases were very similar. There was extensive endocardial fibroelastosis involving all four chambers of the heart and cystic enlargement of the lymph nodes.

These cases raise the possibility that the cardiac lesions in endocardial fibroelastosis are merely local manifestations of a generalized disease.

We should like to thank Dr. C. C. Harvey who supplied us with the early history of Case 1, Dr. H. G. Koster who performed the necropsy in Case 2, Dr. J. L. Emery for his help with the pathological findings, and the Photographic Department of the Sheffield United Hospitals for the illustrations. Case 1 was admitted under Professor R. S. Illingworth and Case 2 under Dr. T. Colver, to both of whom our thanks are due for permission to publish and also for helpful criticism.

\section{REFERENCES}

Blumberg, R. W., and Lyon, R. A. (1952). Amer. J. Dis. Child., 84, 291.

Bouvrain, Y., and Bescol-Liversac, J. (1950). Arch. Mal. Cour., 43, 961.

Collier, F. C., and Rosahn, P. D. (1951). Pediatrics, 7, 175.

Craig, J. M. (1949). Bull. Internat. Assoc. med. Mus., 30, 15.

Dennis, J. L., Hansen, A. E., and Corpening, T. N. (1953). Pediatrics, 12, 130.

Gowing, N. F. C. (1953). J. Path. Bact., 65, 13.

Gross, P. (1941). Arch. Path., 31, 163:

Hill, W. T., and Reilly, W. A. (1951). Amer. J. Dis. Child., 82, 579.

Kempton, J. J., Glynn, L. E. (1955). Quart. J. Med., 24, 191.

Prior, J. T., and Wyatt, T. C. (1950). Amer. J. Path., 26, 969.

Weinberg, T., and Himelfarb, A. J. (1943). Bull. Johns Hopkins Hosp., 72, 299. 